\title{
La pierre qui dure
}

De quelques usages contemporains d'objets préhistoriques (Sahara, Yémen)

Dominique Champault

\section{(2) OpenEdition}

12 Journals

Édition électronique

URL : https://journals.openedition.org/tc/707

DOI : $10.4000 /$ tc. 707

ISSN : 1952-420X

Éditeur

Éditions de l'EHESS

Édition imprimée

Date de publication : 1 novembre 1992

ISSN : 0248-6016

Référence électronique

Dominique Champault, "La pierre qui dure », Techniques \& Culture [En ligne], 17-18| 1992, mis en ligne le 10 janvier 2006, consulté le 29 septembre 2022. URL : http://journals.openedition.org/tc/707 ; DOI : https://doi.org/10.4000/tc.707

Ce document a été généré automatiquement le 29 septembre 2022.

Tous droits réservés 


\section{La pierre qui dure}

De quelques usages contemporains d'objets préhistoriques (Sahara, Yémen)

Dominique Champault 